\title{
The Cutoff Values of Epicardial Fat in Metabolic Syndrome, Cardiovascular Risk Factors, Coronary and Carotid Stenosis
}

Leonardo Roever* and Resende ES

Federal University of Uberlandia, Department of Clinical Research, Uberlandia, Brazil

*Corresponding author:Leonardo Roever, Federal University of Uberlandia, Department of Clinical Research Leonardo S Roever-Borges, MHS Av. Para, 1720 - Bairro Umuarama Uberlandia, MG -CEP 38400-902, Brazil, Tel: +553488039878; E-mail: leonardoroever@hotmail.com

Rec Date: July 28, 2015; Acc Date: July 30, 2015; Pub Date: August 3, 2015

Copyright: (C) 2015 Roever L et al. This is an open-access article distributed under the terms of the Creative Commons Attribution License, which permits unrestricted use, distribution, and reproduction in any medium, provided the original author and source are credited.

\section{Editorial}

Epicardial fat (EF) is an important role in inflammation and CVD. $\mathrm{EF}$ is identified in space between the outer wall of the myocardium and the visceral layer of the pericardium, and its thickness was measured perpendicularly on the free wall of the right ventricle at end-systole in three cardiac cycles [1-3].

Iacobellis et al. studied 246 subjects, 58\% had MetS showed with median values of EF thickness of 9.5 (men) and $7.5 \mathrm{~mm}$ (women), significantly higher than those found in subjects without MetS $(\mathrm{P}<$ $0.001)$. The ROC analysis showed that EF thickness of 9.5 and $7.5 \mathrm{~mm}$ maximize the sensitivity and specificity to predict MetS. EF thickness of $9.5 \mathrm{~mm}$ was associated with insulin resistance [4].

Mookadam et al. demonstrated that $\mathrm{EF}>5 \mathrm{~mm}$ was associated with left atrial enlargement, in a cross-sectional study of 97 patients [5].

Pierdomenico et. al. studied 174 Caucasian hypertensive patients, aged $\geq 40$ years, with $(\mathrm{BM})<25 \mathrm{~kg} / \mathrm{m}^{2}$ and waist circumference (WC) $<102 \mathrm{~cm}$ in men and $88 \mathrm{~cm}$ in women, MetS was present $12 \%$ patients. EF was significantly higher in patients with MetS than in those without MetS $(4.0 \pm 0.8$ vs. $2.5 \pm 0.9 \mathrm{~mm}, P<0.01)$. The ROC curve analysis showed that EF significantly improved prediction of MetS when added to BMI and WC. The ROC curve for EF alone indicated that the cutoff value of $3.1 \mathrm{~mm}$ had the best performance in predicting MetS(100\% sensitivity and 79\% specificity) [6].

Chumakova et al. studied the influence of EF thickness and WC on the risk of coronary atherosclerosis in obese patients with CHD (138 men, $55.47 \pm 9.07$ years and BMI $35.2 \pm 5.2 \mathrm{~kg} / \mathrm{m}^{2}$ ). The ROC analysis reveals that $\mathrm{EF}$ thickness is more informative in diagnosing significant stenosis $(\geq 70 \%)$ (sensitivity $80.4 \%$, specificity- $67.6 \%$; cut-off value $=6$ $\mathrm{mm})$ [7].

Cetin et al. studied the relationship of echocardiographic EF thickness with carotid intima-media thickness, in patients with type 2 diabetes mellitus. A cutoff high risk EF thickness value of $6.3 \mathrm{~mm}$ showed a sensitivity $(72,5 \%)$ and specificity $(71.7 \%)$, respectively, for the prediction of subclinical carotid atherosclerosis [8].

Cabrera-Rego et al. reported a cross-sectional study on 239 patients with suspected disorders of carbohydrate metabolism. EF thickness $\geq 4.9 \mathrm{~mm}$ evidenced $85 \%$ sensitivity and $75 \%$ specificity to predict insulin resistance, with an area under the ROC curve of 0.815 (95\% CI 0.759-0.871). EF had a significant an $\mathrm{i}$ association with insulin resistance and a significant correlation with carotid intima-media thickness in the group of patients with HOMA-IR >2.6 [9].

Knowledge of the cutoff thickness of epicardial fat can detect metabolic changes in patients with cardiovascular risk factors and coronary and carotid stenosis.

\section{References}

1. Roever L, Casella-Filho A, Dourado PMM, Chagas ACP (2014) Ectopic Cardiac Depots, Inflammation and Cardiovascular Disease. General Med 2: 137.

2. Whayne TF Jr (2013) Epicardial fat thickness in heart failure and other clinical conditions. Angiology 64: 169-172.

3. Dey D, Nakazato R, Li D, Berman DS (2012) Epicardial and thoracic fat Noninvasive measurement and clinical implications. Cardiovasc Diagn Ther 2: 85-93.

4. Iacobellis G, Willens HJ, Barbaro G, Sharma AM (2008) Threshold values of high-risk echocardiographic epicardial fat thickness. 16: 887-892.

5. Mookadam F, Goel R, Alharthi SM, Jiamsripong P, Cha S (2010) Epicardial Fat and Its Association with Cardiovascular Risk: A Cross-Sectional Observational Study. Heart Views 11: 103-108.

6. Pierdomenico SD, Pierdomenico AM, Neri M, Cuccurullo F (2011) Epicardial Adipose Tissue and Metabolic Syndrome in Hypertensive Patients With Normal Body Weight and Waist Circumference. Am J Hypertens 24: 1245-1249.

7. Chumakova GA, Veselovskaya NG (2012) Clinical Importance of Epicardial Fat Thickness Defining in Obese Patients. IJBM 2: 161-168.

8. Cetin M, Cakici M, Polat M, Suner A, Zencir C, et al. (2013) Relation of Epicardial Fat Thickness with Carotid Intima-Media Thickness in Patients with Type 2 Diabetes Mellitus. International Journal of Endocrinology ID: 769175: 1-6

9. CAbrera-rego JO, Gandarilla-sarmientos JC, Busto-mesa AD, Valientemustelier J (2012) Association Between Epicardial Fat, HOMA-IR and Carotid Intimamedia Thickness. Revista aArgentina de Cardiologia 80: 222-229. 